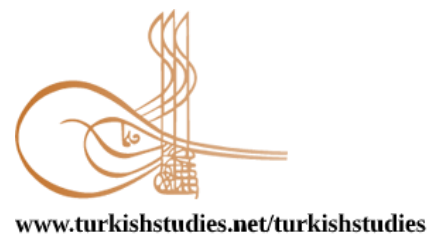

Turkish Studies

\title{
Ortaokul Öğrencilerinin Covid-19’a Yönelik Metaforik Algıları
}

\author{
Covid-19 Perception in Middle School Student' Mind
}

\author{
Aslı Görgülü Arı*- Kevser Arslan**
}

\begin{abstract}
The world has been faced with the danger of a new type of coronavirus, which, as of December, poses a threat to itself and qualifies as a pandemic. The new coronavirus disease (Covid-19) is a virus identified as a result of research conducted in a group of patients developing in late December in Wuhan Province, China. This virus, identified as Covid-19, has spread very quickly in a short time, first came to Europe and then it has influenced the whole world. It can be said that this virus, which is thought to affect people from all walks of life in society, has also affected students who had to interrupt face-to-face education for a while due to their negative impact on their educational life. Therefore, it is thought that it may be beneficial to determine the effect of the virus on students. Accordingly, it is aimed to reveal the perceptions of the students towards the virus in their minds. With the research, it is aimed to reveal the perceptions of middle school students towards Covid-19 through metaphors. In the study, phenomenology research design based on qualitative research approach was used. The participants of the study are 100 students who are studying at the sixth grade. Within the scope of the research, the data of middle school students "Covid-19.... because it is obtained by completing the sentence. Thus, the students' thoughts about Covid-19 and their perceptions in their minds were tried to be determined. The data obtained after the application were analyzed using content analysis. Metaphors written by students in the analysis of the data were classified according to their common features and frequency values were determined. According to the results obtained, 45 different metaphors about the concept of Covid-19 were produced by the students in the research. They have been associated with the characteristics of the Covid-19 outbreak, such as rapid spread in their minds, infectious, fatal, sickening, and long time to occur. The students mostly used the metaphors of "flu", "lice", "agent", "earthquake", "octopus" when making associations for Covid-19. Based on the perceptions of students' metaphor, suggestions based on the results of the research were made. The negative perceptions of Covid-19 virus on students should be eliminated through their teachers.
\end{abstract}

\section{Structured Abstract: Introduction}

First, in december, a new type of coronavirus was found in a group of patients who had respiratory symptoms such as fever, cough, and shortness of breath in Wuhan Province in China. On 13 January 2020,

\footnotetext{
*Doç. Dr. Yıldız Teknik Üniversitesi, Eğitim Fakültesi, Matematik ve Fen Bilimleri Eğitimi Bölümü Assoc. Prof. Ylldiz Technical University, Faculty of Education, Department of Mathematics and Science Education ORCID 0000-0002-6034-3684 
this virus was identified as Covid-19 (T.C Ministry of Health, 2020). The Covid-19 outbreak was declared as a pandemic by the World Health Organization on 11 March 2020 (WHO, 2020). The first case of this virus, which has become a global epidemic and affects the whole world, was announced by the Ministry of Health on March 11 within the scope of our country. As of the date of the first case, the virus spread rapidly in our country. This virus, which shows its effect in the borders of our country, has been widely seen in other cities, especially in Istanbul. The new type of coronavirus has also affected the education sector, especially the health sector. After the health sector, education sector was one of the sectors most affected by this situation (Telli Yamamoto and Altun, 2020: 25). Within the scope of Covid-19 measures, many decisions have been taken at the national level regarding each service sector. One of the decisions taken at the national level on the basis of education sector was to take a break from face to face education. In order to protect the health of students, teachers and parents, it has been decided to have a holiday in all schools affiliated to the Ministry of National Education, starting from the second week of March (National Education Report, March 2020). With the closure of school and university educational institutions around the world, it has been stated with the current data that 770 million learners (students, etc.) have been affected (Zhong, 2020). It is seen that metaphor analyzes are frequently used by researchers to reveal mental images (Polat, Apak and Akdağ, 2013: 62). Metaphors are defined by Arslan and Bayrakçı (2006: 106) as a powerful mental mapping and modeling mechanism for individuals to make sense and structure their own world. Metaphors can be expressed as a powerful "pedagogical tool" that can be used to reveal, understand and change the mental images that individuals have or create regarding certain phenomena (Saban, 2008: 490). Due to this epidemic that manifests itself and spreads rapidly, it is inevitable that students who are thought to be the main subjects of education are not affected by this situation. Therefore, it is expected that this epidemic may have been perceived differently in each student's mind and gained a place. Accordingly, it has been deemed appropriate to use metaphors to reveal students' perceptions of Covid-19. In this context, in the study, the perceptions of students in the sixth grade of secondary school towards the Covid-19 outbreak were tried to be revealed through metaphor. Based on the purpose of the research, the research questions are shaped and it is aimed to produce answers to the questions determined at the end of the research. The research questions in which the answer is sought are stated in the order.

- What are the metaphor perceptions of 6th grade students towards Covid-19 outbreak?

- Under which conceptual categories can the metaphors produced for the Covid-19 outbreak be collected according to their similarities and differences?

\section{Method}

In the study, phenomenology research design based on qualitative research approach was used. The participants of the research are 100 students who study at the sixth grade level in a study center in the 20192020 academic year. While determining the study group of the research, easily accessible case sampling method was preferred. Within the scope of the research, data were collected through a form with an openended question in order to determine students' metaphor perception. The forms were presented to the participants online and a guideline with the necessary explanations for the participants was added to the form. In this direction, 6th grade students' "Covid-19 is .......... like, because...." they were asked to complete the sentence. Content analysis was used in the analysis of the data obtained from the students' answers.

\section{Results}

In line with the research, a total of 45 valid metaphors were obtained from the students who participated in the study. The metaphors produced by students for Covid-19 were categorized under 6 themes, namely "Contagiousness", "Fatal", "Diseased", "Dismissal from Social Environments", "Late Difference" and "Relationship with Other Diseases". When the reasons for all the Covid-19 metaphors produced by the students were examined, it was seen that the metaphors produced were negative. As a matter of fact, it would be correct to say that this epidemic has a negative effect on students. It is understood that the students who constantly hear the deaths due to Covid-19 virus and the increasing number of positive cases in the media agenda have identified this outbreak with negative thoughts.

\section{Conclusion and Recommendations}

No metaphoric research regarding the Covid-19 outbreak, which we can compare results similar to our study in the literature, has been encountered. However, the metaphors produced by the students regarding the Covid-19 outbreak coincide with some metaphors produced in other metaphor studies. Y1lmaz, Özer and 
Fettahoğlu (2020: 121) are under the category of "Being Versatile", the "Octopus" metaphor produced in a metaphor study on health. The "Octopus" metaphor produced in our study was placed under the category of "Covid-19 as an Effective Infectious Contagious". Although the octopus metaphor produced in both studies seems to have made a very different meaning in both studies, it is actually close to each other. Because while the octopus metaphor in our research, Covid-19 stated the meaning that the epidemic can reach and spread anywhere just like octopus arms; in other research it indicates the meaning of the health manager reaching every branch. This, in fact, can be said that two metaphors in categories that seem distant to each other are closely related in both studies. Beyoğlu and Ergin (2019: 290), In a study conducted for prospective teachers, it was tried to reveal the metaphors of teachers about the concept of violence. The earthquake metaphor produced in this study has been included under the category of "Physical Violence". The "Earthquake" metaphor produced in our study was included under the category of "Covid-19 as a Killer Effect". Although the earthquake metaphor produced in both studies seems to have made a very different meaning in both studies, it is actually close to each other. The earthquake metaphor produced in our study identified the feature that Covid-19 epidemic had a devastating effect on people such as earthquakes and even caused deaths.

Keywords: Education, Covid-19, Epidemic, Metaphor, Mind Perceptions, Secondary School Students.

Öz: Dünya, aralık ayı itibariyle kendisi için tehdit oluşturan ve bir pandemi olarak nitelendirilen yeni tip koronavirüs tehlikesi ile karşı karşıya kalmıştır. Yeni koronavirüs hastalığı (Covid-19), Çin'in Wuhan Eyaleti'nde aralık ayı sonlarında ortaya çıkan solunum yolu belirtileri şeklinde gelişen bir grup hastada yapılan araştırmalar sonucunda tanımlanan bir hastalıktır. Covid-19 olarak tanımlanan bu virüs, kısa sürede çok hızlı bir yayılım göstererek önce Avrupa'yıdaha sonra da tüm dünyayı etkisi altına almıştır. Toplumda yer alan her kesimden insanı etkileyen bu virüs, eğitim hayatını da etkilemiş ve yüz yüze eğitime bir süreliğine ara verilmiştir. Bu nedenle virüsün öğrenciler üzerinde oluşturduğu etkinin belirlenmesinin faydalı olabileceği düşünülmüştür. Bu doğrultuda bu çalışmada, öğrencilerin zihinlerinde virüse yönelik oluşan algılarının ortaya çıkarılması hedeflenmiş ve hedefe ulaşabilmek için ortaokul öğrencilerinin Covid-19'a yönelik algılarının, metaforlararacılığyla ortaya çıkarılmasısağlanmıştır. Çalışmada nitel araştırma yaklaşımına dayalı olgu bilim araştırma deseni kullanılmıştır. Çalışmanın katılımcılarını 6. sınıf düzeyinde öğrenim görmekte olan toplam 100 öğrenci oluşturmaktadır. Araştırma kapsamında veriler, ortaokul öğrencilerinin "Covid-19 ... gibidir, çünkü...." cümlesini tamamlamasıyla elde edilmiştir. Böylelikle öğrencilerin Covid-19’a ilişkin düşünceleri ve zihinlerinde oluşturdukları algıları tespit edilmeye çalışılmıştır. Uygulama sonrası elde edilen veriler içerik analizi ile çözümlenmiştir. Verilerin analizinde öğrenciler tarafından yazılmış olan metaforlar kendi içinde ortak özelliklerine göre sınıflandırılmış, frekans değerleri belirlenmiştir. Elde edilen sonuçlara göre, araştırmada öğrenciler tarafından Covid-19 kavramına ilişkin 45 farklı metafor üretilmiştir. Öğrencilerin Covid-19 salgınını zihinlerinde hızlı yayılım, bulaşıcı, öldürücü, hasta edici, ortaya çıkma süresi uzun hastalık şeklinde kelimeler ile ilişkilendirdikleri görülmüştür. Öğrenciler Covid-19'a yönelik ilişkilendirme yaparken en çok "grip”, “bit”, “ajan”, “deprem”, "ahtapot” metaforlarını kullanmıştır. Öğrencilerin oluşturmuş oldukları metafor algılarından yola çıkılarak, araştırma sonuçlarına dayalı önerilerde bulunulmuştur. Covid-19 hastalığının öğrenciler üzerinde oluşturmuş olduğu olumsuz algılar bu çalışma ile de tespit edilmiştir ve olumsuz yaklaşımların öğretmenleri aracılığıyla ortadan kaldırılması önerilebilir.

Anahtar Kelimeler: Eğitim, Covid-19, Salgın, Metafor, Zihin Algıları, Ortaokul Öğrencileri.

\section{Giriş}

Birçok insanın ismini dahi bilmediği ancak çoğu insanın grip benzeri semptomlarla atlattığı yeni tip koronavirüs hastalığı, 2019 yılı sonlarında yayılım hızı yüksek ve öldürücülük kapasitesi önceki türlerine göre artış göstermiş yeni şekliyle karşımıza çıkmıştır. İlk olarak Çin'in Wuhan Eyaleti'nde aralık ayında, ateş, öksürük, nefes darlığı gibi solunum yolu belirtileri gözlemlenmiş, bir grup hastada yapılan araştırmalar sonucunda yeni bir tip koronavirüse rastlanmıştır. 13 Ocak 2020'de ise bu virüs Covid-19 olarak tanımlanmıştır (T.C Sağlık Bakanlığı, 2020). Coronavirus ailesi uzmanlar tarafindan daha önce Sars-CoV ve Mers-CoV salgınlarından dolayı can kaybına yol 
açan bir virüs olarak bilinmektedir. Ancak aralık ayı itibariyle onlara kıyasla adını daha çok duyduğumuz ve yine onlara kıyasla daha çok insana yayılan yeni tip korona virüs ile ortaya çıkmıştır. Covid-19 hastalığına neden olan virüs, sahip olduğu bulaştırıcı özelliği ile diğer virüs tiplerine nazaran daha tehlikeli bir hal almış ve dünya için tehdit saçan bir unsur olmuştur. Burada en önemli nokta, Covid-19 hastalığına yakalanmış hastanın bulaştırıcı olması ve hastalığı çevreye yaymasıdır (Karcıoğlu, 2020: 56). Virüsün çok kısa bir süre içerisinde, önce Çin, ardından İran, daha sonra Avrupa ülkelerinde ve daha sonra da Amerika kıtasında görülmüş olmasının, yeni tip korona virüsün yayılım hızının ne denli yüksek olduğuna kanıt oluşturduğu söyelenebilir. Öte yandan öldürücü etkisi göz önüne alındığında, Mart 2020'de Covıd-19, Sars ve Mers hastalıklarının toplamından daha fazla zarara ve ölüme yol açmış olduğu belirlenmiştir (Karcıoğlu, 2020: 56).

Covid-19 hastalığı, 11 Mart 2020 tarihiyle Dünya Sağlik Örgütü tarafından pandemi olarak ilan edilmiştir (WHO, 2020; İnce, Yağlı, Sağlam ve Kütükcü, 2020: 82). Küresel bir salgın haline gelen ve tüm dünyayı etkisi altına alan bu virüsün, ülkemiz kapsamında ilk vakası 11 Mart tarihinde Sağlık Bakanlığı tarafından açıklanmıştır. İlk vakanın ortaya çıktığı tarih itibariyle virüs, ülkemizde hızlı bir biçimde yayılım göstermiştir. Ülkemiz sınırlarında etkisini gösteren bu virüs, en yoğun olarak İstanbul ilinde olmak üzere diğer illerimizde de yaygın şekilde görülmüştür. Çıkış tarihinden itibaren, 16 Haziran 2020 tarihine kadar pozitif sonuçlanan test sayısı toplamda 180.000 'i aşmıştır. Bu pozitif bireylerin 4.842 'sinin ise virüse yenik düşerek vefat etmiş olduğu bakanlık tarafından açıklanmıştır (Sağlık Bakanlığı, 2020).

Yeni tip koronavirüs hastalığı nedeniyle sağlık sektöründen sonra en çok etkilenen sektörlerin başında eğitim sektörü gelmiştir (Telli, Yamamoto ve Altun, 2020: 25). Covid-19 önlemleri kapsamında her bir hizmet sektörüne ilişkin ulusal düzeyde birçok karar alınmıştır. Eğitim sektörü bazında ulusal düzeyde alınmış kararlardan biri ise yüz yüze eğitime bir süre ara verilmesi olmuştur. Öğrenciler, öğretmenler ve velilerin sağlı̆̆ının korunması amaciyla ülke genelinde Milli Eğitim Bakanlığı'na bağlı tüm okullarda mart ayının ikinci haftasından itibaren uzaktan eğitim sürecine geçilerek tatil edilmesi kararlaştırmıştır (Milli Eğitim Raporu, Mart 2020). Dünya üzerinde okul ve üniversite eğitim kurumlarının kapanmasıyla beraber 770 milyon kişilik öğrenen kitlenin etkilenmiş olduğu güncel verilerle belirtilmiştir (Zhong, 2020).

Çocuklar, yüz yüze eğitime ara verilmesiyle geçilen uzaktan eğitimle değişen yeni ev düzenine hemen uyum sağlamakta zorluklar çekebilmektedir. Dolayısıyla da bu durumdan öğretmenler ve velilere nispeten eğitim sektörünün esas öznesi olarak görülebilenöğrencilerin dahafazla etkilendiği söylenebilir (Türkiye Çocuk ve Genç Psikiyatrisi Derneği, 2020: 20). Öğrencilerin üzerinde meydana gelen etkiye bireylerin sürekli iç içe olduğu öğretmenlerinden ve arkadaşlarından ayrı kalması, örgün okul yaşamlarının bir anda sekteye uğraması gerekçe olarak gösterilebilir. Öğrenci ve öğretmenlerinin yaşam standartlarının ve alışkanlıklarının sosyal izolasyon gerekçesiyle sınırlandırılmış olması kendilerini kötü hissetmelerine sebebiyet verebilmektedir (Sarı ve Nayır, 2020:970). Öte yandan öğrencilerin vakit geçirdiği düşünülen tiyatro, sinema, gösteri merkezi, konser salonu, her türlü kapalı oyun alanları (alışveriş merkezi ve lokanta içindekiler dâhil), lunapark, yüzme havuzu gibi alanlar T.C İçişleri Bakanlığı Genelgesi (16.03.2020) ile geçici olarak kapatılmıştır (İçişleri Bakanlığı, 2020). Çocuklar ve gençlerde ileriki yaşamlarını sağlıklı bir şekilde devam ettirebilmeleri ve toplumun sağliklı bir üyesi olabilmeleri için gün içerisinde en az 60 dakika fiziksel aktiviteye katılım göstermeleri önerilmektedir (CDC, 2013; THSK, 2014). Bu öneri göz önüne alındığında, gerekmedikçe dışarı çıkılmaması fiziksel aktivitelerin gerek duyulduğu bu dönemde öğrenciler için negatif bir etki yaratmış olabileceği düşünülmektedir. Ayrıca diğer dönemlere nazaran daha enerjik ve hareketli olarak kabul edilebileceği ergenlik döneminde bulunan ortaokul öğrencileri üzerinde bu negatif etkinin daha fazla olabileceği öngörülmektedir.

Ergen olarak kabul edilen ortaokul dönemi öğrencileri ruhsal, zihinsel, motor, sosyal becerilerini kazanmalarını sağlayan faktörler akran grupları ve okuldur. Covid-19 salgını nedeniyle 
gündelik yaşamın askıya alınması, aile dışı ve aile içi rutinlerin bozulması ile çocukların ruhsal, sosyal, akademik, motor, zihinsel gelişimlerini sekteye uğratabilir. Bununla beraber farklı psikiyatrik sorunların ortaya çıkmasına zemin oluşturabilir veya var olan bazı problemlerin ağırlaşmasına yol açabilir (Türkiye Çocuk ve Genç Psikiyatrisi Derneği, 2020: 4). Bu doğrultuda Covid-19 salgını süreci içerisinde ortaokul öğrencilerinin psikolojik, sosyolojik ve duygusal anlamda olumsuz yönde etkilenmiş olduğunu söylemek yanlış olmayacaktır.

Yüz yüze eğitime ara verilmesiyle uzaktan eğitime geçen ve ev ortamına kapalı kalmak zorunululuğu yaşayan ortaokul öğrencileri, Covid-19 salgınına ilişkin zihinlerinde farklı algılar oluşturmuş olabileceklerdir. Ortakul dönemindeki öğrencilerin belki de ilk kez karşı karşıya kaldıkları salgına ve sürecine yönelik zihinlerinde şekillendirdikleri algıların sorgulanması ile önemli bilgiler elde edilecektir. Öğrencilere var olan düşüncelerin ortaya çıkarılmasında eğitimde yer alan yararlanılabilecek pek çok teknik mevcutur. Ancak araştırma kapsamında salgına yönelik fikirlerin açığa çıkarılmasında araç olarak metaforlardan faydalanılmıştır. Metaforlar, bireylerin örgüt yapısını nasıl anlamlandırdıklarını ve onu ne şekilde algılamış olduklarına ilişkin benzetimlerini, örgüt ile arasındaki bağlantısı hakkında önemli ipuçlarını ortaya çıkarabilmektedir.

Metaforlar, Arslan ve Bayrakçı (2006:106) tarafindan fertlerin kendi dünyalarını anlamlandırabilmelerine ve yapılandırabilmelerine ilişkin güçlü bir zihinsel haritalama ve modelleme düzeneğidir şeklinde tanımlanmıştır. Metaforlar, bireylerin belirli olgulara ilişkin sahip oldukları veya oluşturdukları zihinsel imgeleri açığa çıkarmak, anlamak ve değiştirmek amacıyla kullanılabilen güçlü bir "pedagojik araç" olarak ifade edilebilir (Saban, 2008: 490). Diğer yandan Botha (2009:433), tarafından eğitim alanında metaforların bir tür iletişim biçimi olduğu ve sezgisel olarak bulguları ortaya çıkarmada bir araç olarak kullanılması gerektiği belirtilmiştir. Kısacası bir kavram ya da konuya dair öğrencilerin görüşlerinin açığa çıkarılıp belirlenmesinde mateforların yeri yadsınamaz (Saban, 2009:319). Bu bağlamda metaforların, bireylerde var olan algılarının önemli ve uygun noktalarını ön plana çıkartıp anlaşılmasını sağlayarak, tüm gerçekliğiyle ortaya çıarabilecek son derece önemli kaynaklardan biri olduğunu ileri sürülebilir.

Alanyazın incelendiğinde metaforun kullanımına yönelik pek çok çalışmanın gerçekleştirildiği görülmektedir. Bu çalışmalar, sosyal bilimlerin farklı disiplinlerinde farklı kavramlara yönelik olarak gerçekleştirilmiştir. Eğitimde de metafor kullanımı hem ulusal hem de uluslararası düzeyde çalışmalarda yer almaktadır (Başer ve Yapıcı, 2018; Geçit ve Gençler, 2010 ; Kalaycı ve Yoğun, 2018; Kurt ve Sarı, 2017 ; Uğurlu, 2018; Türküresin, Başer ve Yapıcı (2018), ortaokul öğrencilerinin dayanışma kavramına yönelik algılarını metaforlar ile ortaya çıkarmayı hedeflemişlerdir. Öğrencilerin dayanışma kavramına ilişkin 73 farklı metafor ürettiği gözlenmiş ve bu metaforlar dört farklı tema altında toplanmıştır. Kalaycı ve Yoğun (2018), ortaokul öğrencilerinin "alyuvar", "akyuvar" ve "kan pulcukları" kavramlarına yönelik sahip oldukları algıları metaforlar aracılığıyla incelemişlerdir. Çalışma sonucunda öğrencilerin "alyuvar" kavramı için 74 metafor, "akyuvar" kavramı için 63 metafor ve "kan pulcukları" kavramı için de 60 metafor ürettikleri görülmüştür. Uğurlu (2018) ise üniversite kavramına ilişkin algıların ortaya çıkarılması amaciyla öğretmen adaylarına yönelik metafor analizi gerçekleştirmiştir. Öğrencilerin üniversite kavramına yönelik oluşturmuş oldukları 74 adet metafor beş farklı kategori altında toplanmıştır.

Eğitim alanında birçok metafor çalışması yer alırken, sağlık alanında da metafor araştırmaları mevcuttur. Abay (2017), araştırmasında tıp fakültesi öğrencilerinin hekim kavramına yönelik metafor algılarını tespit etmeyi amaçlamıştır. Çalışma sonucunda öğrencilerin üretmiş oldukları 248 metafor olduğu ve bu metaforların beş farklı kategoride sınıflandırılmış olduğu görülür. Yılmaz, Özer ve Fettahoğlu (2020), sağlık alanında bir metafor çalışması gerçekleştirmiştir. Araştırmada sağlık yönetimi bölümü öğrencilerinin "sağlık yöneticisi" kavramına yönelik sahip oldukları algılar metaforlar aracılığıyla belirlenmiştir. Araştırma sonucunda sağlık yöneticisi kavramında yönelik sekiz farklı kategoride metafor üretildiği görülmüş̧ür. 
Covid-19 literatürü incelendiğinde, ülke gündemine oturan Covid-19 salgının birçok araştırmacı için çalışma konusu olduğu görülmektedir. Covid-19 pandemisine yönelik farklı konulara değinmeyi hedefleyen, çoğu sağlık alanına yönelik pek çok çalışmaya rastlanmıştır (Eskici, 2020; Gökçay ve Keskindemirci, 2020; Gümüşgül ve Aydoğan, 2020; Ovalı, 2020; Telli Yamamoto ve Altun, 2020; Tırmıkçıŏlu, 2020).

Gümüşgül ve Aydoğan (2020:107), çalışmalarında bireylerin yeni tip koronavirüs kaynaklı evde kalınan zamanlarda uygulayabilecekleri ev içi rekreatif oyunların incelenmesi amaçlanmışlardır. Araştırma doküman incelemesi ve tarama modeli ile yürütülmüştür. Araştırmada yeni koronavirüs ile ilgili alanyazın taraması yapılmış ve yeni koronavirüs kaynaklı bakanlık ve uzmanlar tarafından önemle tavsiye edilen zorunda olmadıkça dışarı çıkılmaması gerektiğine istinaden evde kalınan boş zamanlarda oynanabilecek rekreatif oyunlar tasarlanmıştır. Telli Yamamoto ve Altun (2020:25), çalışmalarında Covid-19 hastalığı önlemleri kapsamında ülkelerin ve üniversitelerin eğitim öğretime ara vermemesini sağlamak adına bir zorunluluk haline gelen uzaktan eğitim çalışmalarının bir değerlendirilmesi yapılmıştır. Bu bağlamda durum tespiti yapılarak bir anda yükselen çevrimiçi öğrenmenin yükselişinin konu alınmıştır.

Özetle, hem Covid-19 pandemisinin konu alındığı çalışmalar hem de metaforlardan yararlanılan çalışmaların varolduğu görülmektedir. Ancak Covid-19 salgınına ilişkin bir metaforik araştırmaya rastlanmadığ görülmektedir. Bu bağlamda Covid-19 hastalığına ilişkin bir metafor çalışmasının yapılmasının alanyazına katkı sağlayabileceği düşülmektedir. Tüm dünyayı etkisi altına alan ve ülkemizde mart ayı itibariyle etkisini gösteren Covid-19 hastalığı toplumdaki bireyler üzerinde son derece büyük etkiler yaratmıştır. Dolayısıyla da bu denli etki yaratan virüsün ortaokul öğrencileri üzerinde yaratmış olduğu etkinin tespit edilmesi önemli bulunmuştur. Metaforlar, insanların hayatı, çevreyi, olayları ve nesneleri nasıl gördükleri; farklı benzetmeler kullanarak açıklamaya çalışmada kullandıkları araçlar olarak düşünülmektedir (Cerit, 2008:694). Metaforlar farklı kavramları yapılandırmada ve kavramları somutlaştırmada en iyi zihinsel araçlardır (Shaw ve Mahlios, 2011:78). Bu doğrultuda ortaokul öğrencilerinin Covid-19 hastalığına yönelik zihinlerinde oluşturmuş oldukları algıları belirlemede metaforlardan faydalanılmıştır. Ayrıca Covid-19 pandemisine ilişkin metafor çalışmasına rastlanmamış olunması, bu konuda araştırma yapacak kişiler için bir kılavuz görevi göreceği düşünülmektedir. Covid-19 salgınına ilişkin öğrencilerim zihinlerinde var olan algılar, salgın sonrası gerçekleştirilecek eğitimin şekillendirilmesinde önemli fikirler verebilecek potansiyeli sahiptirler. Öğrencilerin bu sürece ilişkin oluşturdukları düşüncelerin sorgulanması, salgın sürecinin devamında veya sonrasında verilecek eğitim faliyetlerine farklı bir perspektiften bakabilme olanağı tanıabilecektir. Dolayısıyla da virüs tehlikesi son bulduğunda ve öğrenciler okullarına döndüğünde, öğretmenlerin araştırmadan elde edilen kavramlar aracılığıyla öğrencilere daha kolay yardımcı olabileceği düşünülmektedir. Her bir öğrencinin kendi dünyasında anlamlandırdığı kavramların ortaya çıkarılması, farklı bireylerin bakış açıları aracılığıyla daha çeşitli ilişkiler kurulmasını sağlayabilecek ve daha geniş çaplı öneriler sunulabilmesine fayda oluşturabilecektir. Bu çalışmanın hem araştırmacılara hem de eğitimcilere önemli düzeyde yarar sağlayacağı beklenmektedir.

Araştırmada ortaokul öğrencilerinin zihinlerinde Covid-19 virüsüne yönelik oluşan algılarının metaforlar aracılığıyla ortaya çıkarılması amaçlanmış ve bu amaç doğrultusunda aşağıdaki sorulara yanıt aranmıştır.

1.6.sınıf öğrencilerinin Covid-19'a yönelik metaforik algıları nelerdir?

2.Covid-19'a yönelik üretilen metaforlar, benzerlik ve farklılıklarına göre hangi kavramsal kategoriler altında toplanabilir?

\section{Yöntem}

Araştırmanın modeline, çalışma grubuna, veri toplama aracına, veri analizine ve çalışmanın güvenilirliğine yönelik bilgilere bu bölümde yer verilmiştir. 


\section{Araştırma Modeli}

Çalışmada nitel araştırma desenlerinden dayalı fenomenoloji (olgubilim) desen kullanılmıştır. Olgubilim deseninde bilgi üretmek ve bir olguya yönelik gerçekliğin ortaya çıarmak hedeflenmektedir (Creswell, 2015: 77; Patton, 2014:238). Bu desen daha çok insanın iç dünyasını ve onların bilinç yapılarını anlamaya çalışır (Mayring, 2011:110). Olgubilim, bir olgunun daha iyi anlaşılmasına yardımcı olduğundan bilimsel çalışmalara katkıda bulunmaktadır (Yıldırım ve Şimşek 2018:72-75). Ayrıca karmaşık kavram, olay ve olguların derinlemesine araştırılmasında etkili bir yöntem olan metafor analizi, önemli bir nitel araştırma yöntemi olarak görülmektedir (Güneş ve Fırat, 2016:125).

\section{Çalışma Grubu}

Araştırmanın çalışma grubunu 2019-2020 eğitim-öğretim yılında İstanbul İli’nde yer alan bir devlet okulunun altıncı sınıf düzeyinde uzaktan öğrenim gören toplam 100 öğrenci oluşturmaktadır. Bu öğrencilerin 65 'i kız, 35'i ise erkektir.

Araştırmanın çalışma grubu belirlenirken kolay ulaşılabilir durum örnekleme yöntemi tercih edilmiştir. Amaçlı örnekleme tekniklerinden biri olan kolay ulaşılabilir durum örneklemesi, araştırmacının yakın ve erişilmesi kolay durumları seçtiği bir örnekleme tekniği olup, araştırmacıya hız ve pratiklik kazandırmaktadır (Yıldırım ve Şimşek, 2018:113). Dolayısıyla da araştırma kapsamında en kısa sürede ve en hızlı ulaşılabilecek öğrenciler seçilmiştir.

\section{Verilerin Toplanması}

Araştırma verileri metaforik algı formu aracılığı ile toplanmıştır. Formlar katılımcılara online ortamda sunulmuş ve katılımcılara yönelik gerekli açıklamaların yapıldığ formlara eklenmiştir.

Kat1lımcıların algılarının belirlenmesinde metafor formlar1, veri toplama aracı olarak kullanılabilmektedir (Kılcan, 2017:13). Alan yazındaki çalışmalar incelenmiş (Aydeş, 2016:24; Bülbül ve Toker-Gökçe, 2015:278-279) ve çoğu araştırmacının metafor çalışmalarında kullanmış olduğu soru türü esas alınmıştır. Bu doğrultuda öğrencilerin "Covid-19 ....... gibidir, çünkü ......." cümlesini tamamlamaları istenmiştir. Her bir katılımcının Covid-19 kavramını herhangi bir şeye benzetmeleri istenmiş; çünkü ....... şeklinde bırakılan boşluğa ise gerekçe yazmaları beklenmiştir. Metaforun bir araştırma aracı olarak kullanıldığı çalışmalarda; metaforun konusu ile kaynăğ arasındaki bağı daha açık bir şekilde çağrıştırmak amacıyla "Gibi" kavramına, araştırmacıların kendi metaforlarına gerekçelerini sunmaları için "çünkü" kavramına yer verildiği görülmektedir (Akın ve Minaz, 2018; Arslan ve Zengin, 2016:455; Öksüz ve Çevik-Kansu, 2014:56; Saban, 2009:285; Taş, 2019:38)

\section{Veri Analizi}

Öğrencilerin cevaplarından elde edilen verilerin analizinde içerik analizinden faydalanılmıştır. İçerik analizinde temel amaç birbirine benzeyen verileri belirli kavramlar ve temalar çerçevesinde biraraya getirmek ve toplanan verileri açıklayabilecek ilişkilere ulaşmaktır (Yıldırım ve Şimşek, 2018:187, 227).

Araştırma kapsamında öğrencilerden elde edilen veriler analiz edilirken; Ekici (2016:760761) tarafindan kullanılan metafor analiz çözümleme aşamalarından yararlanılmıştır. İlk aşamada, veri toplama aracı olarak kullanılan metafor formları incelenmiş ve metafor formlarının öğrenciler tarafından uygun bir şekilde doldurulup doldurulmadığ 1 kontrol edilmiştir. Metafor yazılmayan ve metafor yazılmış olsa bile çünkü cümlesi tamamlanmayan, mantıklı bir açıklaması yapılmayan formlar değerlendirilme işleminden ayrı tutulmuştur. Bu şekilde her bir form incelenerek katılımcılardan toplanan verilerden metafor özelliği göstermeyen cevaplar ve boş bırakılan formlar elenmiştir. Elenme işlemi sonucunda 10 adet formun değerlendirmeye alınmamasına karar 
verilmiştir. Eleme sonrasında metafor özelliği gösteren formlar tekrar okunarak incelenmiştir ve her bir form numaralandırılmıştır. Düzenlenen metaforlar okunmuş ve benzer anlamlar ifade eden metaforlar bir araya toplanmıştır. Benzer özellikler esas alınarak bir araya getirilen metaforların kategorize edilme aşamasına geçilmiştir. Üretilen metaforlar katılımcıların sunmuş olduğu gerekçeler doğrultusunda araştırmacılar tarafından kategorize edilmiştir. Kategorize edilen metaforların temsil ettiği özellik temel alınarak kategorilere uygun adlandırmalar yapılmıştır. Her bir kategoriye ait metafor tabloları oluşturulmuştur. Son olarak her bir metaforun sahip olduğu frekans değerleri hesaplanarak tabloya yazılmıştır. Son aşamada ise veri analizi sonucunda elde edilen bulguların geçerlik ve güvenirliği sağlanarak yorumlanmıştır (Ekici, 2016:762). Verilerin incelenmesiyle ortak yönler bulunmuş ve kategoriler düzenlenmiştir ve frekans sıklıkları belirlenmiştir. Ayrıca tüm metaforların görülebilmesi açısından, tüm metaforların yer aldığı genel bir frekans tablosu da hazırlanmıştır. Araştırmacılar tarafindan oluşturulan her bir tablo ayrıntılı bir şekilde kendi kategorilerde değerlendirilmiştir. Ayrıca kategorilerde yer verilen metaforlara yönelik öğrenci cümlelerine de yer verilmiştir. Analiz sürecinde metafor formlarına yönelik yapılan numaralandırma işlemi öğrenci sıralamasını temsil edecek biçimdedir. Her bir öğrenci Ö1, Ö2, Ö3,........ Ö90 şeklinde kodlanmıştır.

\section{Güvenirlilik ve Geçerlilik}

Gerçekleştirilen çalışmanın farklı araştırmacılar tarafından incelenmesi ve yorumlanması araştırmanın tutarlılığını ve anlaşılabilirliğini arttırır (Yıldırım, 2010:81-82). Bu bağlamda veriler başka bir araştırmacı tarafindan da incelenmiş ve oluşturulan kodlar arasında uzlaşı olup olmadığına bakılmıştır. Farklı araştırmacıların aynı verileri yorumlayarak analiz edebilmesi ve bunların kıyaslanması güvenirliğin sağlanması açısından önemlidir (Erişti, 2014:89; Merriam, 2013).

Oluşturulan temalar için güvenirlik hesaplaması Miles ve Huberman'ın güvenirlik formülü kullanılarak hesaplanmıştır. Güvenirlik kat sayısı fikir birliği bulunanların, fikir birliği bulunan ve fikir birliği bulunmayanların toplamına bölünüp 100 ile çarpılmasıyla hesaplanır. Değerin en az 80 olması gerekmektedir (Miles ve Huberman, 2016:64). Uzmanların birbirinden bağımsız olarak yaptıkları kodlamalar karşılaştırılarak görüş birliği ve görüş ayrılığı sayıları tespit edilmiştir. Elde edilen kodlara yönelik [Görüş birliği / (Görüş birliği + Görüş ayrılığı) x 100] formülü kullanılarak güvenilirlik kat sayısı hesaplanmıştır. Araştırmada kapsamında öğrencilerin toplamda geçerli 45 metafor üretmiş oldukları belirlenmiştir. Bu metaforlardan 5 tanesinde fikir ayrılığı yaşanırken (Kanser, Radyasyon, Mıknatıs, Yalan, Turist), geriye kalan 40 metafor üzerinde görüş birliğine varılmıştır. Her bir veri formülde yerine konulduğunda, ortalama güvenirlik kat sayıs1 \%88,90 olarak bulunmuştur [ $40 /(40+5)$ x 100=\%88,90]. Dolayısıyla da elde edilen güvenirlik sonucu istenilen güvenirlik düzeyine ulaşıldığını göstermektedir.

Metaforları temsil etme durumlarının incelenmesi amacıyla gerçekleştirilen geçerlik çalışmasında iki alan uzmanının görüşlerine başvurulmuştur. Bazı metaforların kategorize edilmesi işleminde alan uzmanları tarafından farklı görüş bildirilmiş olsa da görüşmeler yapılarak uzlaşmaya varılmıştır. Örneğin, öğrenciler tarafından oluşturulan "Kanser" metaforunda görüş farklılı̆̆1 meydana gelmiştir. Uzmanlardan biri kanser metaforunun ölümcül kategorisine dâhil edilmesini önerirken; diğer uzman kanserin vücut içerisinde yayılma göstermesi sebebiyle bulaşıcılık kategorisine dâhil edilmesini önermiştir. $\mathrm{Bu}$ metafor üzerinde tartışılarak kanserin yayılım özelliğinin organlar arasında olduğu ve öldürücü kategorisine dahil edilmesi gerektiği sonucuna varılarak uzlaşma sağlanmıştır.

\section{Araştırmada Etik Süreçler}

Gerçekleştirilen araştırma çerçevesinde, Yıldız Teknik Üniversitesi Akademik Etik Kurulu'ndan (73613421-604.01.02-E2006190265 say1 ve Etik Kurul Karar1 2020/4 Konulu) etik izin alınmıştır. 
Araştırmaya gönüllü olarak katılım sağlayan öğrencilerden alınan cevapların gizlilik ilkesinin çiğnenmeyeceği, elde edilen verilerin bilimsel araştırma dışında diğer amaçlarla asla kullanılmayacağı ve araştırmacı tarafindan kontrolünün her basamakta sağlanacağı açıklanmıştır. Ayrıca katlımcılara, isimleri alınmayarak, kimliklerinin gizleneceği konusunda güvence verilmiştir.

\section{Bulgular}

$\mathrm{Bu}$ bölümde, çalışma grubunda yer alan öğrencilerin “Covid-19" salgınına ilişkin geliştirmiş oldukları metaforlara, bu metaforlar doğrultusunda oluşturulan farklı kavramsal kategorilere ve katılımcıların üretmiş oldukları metaforlara dair alıntılara (katılımcılara ait örnek cümlelere) yer verilmiştir. Verilerin analizi sonucunda ulaşılan bulgular sistematik, mantıklı, tutarlı ve anlaşılır bir şekilde düzenlenerek araştırmanın amacı ve alt amaçları doğrultusunda sunulmuştur.

\section{1. “6.Sınıf Öğrencilerinin Covid-19'a Yönelik Metaforik Algıları Nelerdir?” Alt Problemine İlişkin Bulgular}

Çalışmada elde edilen verilerin analizi sonucunda öğrenciler tarafından geçerli sayılabilecek 45 metafor üretildiği saptanmıştır. Herhangi bir metaforu yazmış olan öğrenci sayısı hesaplanarak, her bir metafora ait frekans değerleri belirlenmiştir. Öğrencilerin Covid-19 salgına yönelik üretmiş oldukları metaforlar ve metaforların frekans değerleri Tablo 1'de sunulmuştur.

Tablo 1: Öğrencilerin Covid-19 Salgına İlişkin Olușturdukları Metaforlar

\begin{tabular}{|c|c|c|c|c|c|}
\hline No & Metafor & $\begin{array}{c}\text { Frekans } \\
(\mathbf{N})\end{array}$ & No & Metafor & $\begin{array}{c}\text { Frekans } \\
(\mathbf{N})\end{array}$ \\
\hline 1 & Grip & 4 & 25 & Sars & 2 \\
\hline 2 & Bit & 4 & 26 & Kalkan & 1 \\
\hline 3 & Ajan & 3 & 27 & Örümcek Ağ1 & 1 \\
\hline 4 & Deprem & 3 & 28 & Kurt & 1 \\
\hline 5 & Bakteri & 3 & 29 & Mantar & 1 \\
\hline 6 & Karadelik & 3 & 30 & Radyasyon & 1 \\
\hline 7 & Bronşit & 3 & 31 & Küçük Tanecik & 1 \\
\hline 8 & Elektrik & 3 & 32 & Silah & 1 \\
\hline 9 & Miknatıs & 3 & 33 & Tipeks & 1 \\
\hline 10 & Dikenli Bir Çiçek & 3 & 34 & Kaza & 1 \\
\hline 11 & Y1lan Zehri & 3 & 35 & Hile & 1 \\
\hline 12 & Turist & 3 & 36 & Abur Cubur & 1 \\
\hline 13 & Şımarık Çocuk & 3 & 37 & Yalan & 1 \\
\hline 14 & Prit & 3 & 38 & Demir Parmaklık & 1 \\
\hline 15 & Ahtapot & 3 & 39 & Kanser & 1 \\
\hline 16 & Sigara & 3 & 40 & Gicık & 1 \\
\hline 17 & Kurşun & 3 & 41 & Canavar & 1 \\
\hline 18 & Tatil & 3 & 42 & Kötü Arkadaş & 1 \\
\hline 19 & Yapışkan Top & 2 & 43 & Yalıtım Malzemesi & 1 \\
\hline 20 & Kötü İnsan & 2 & 44 & Mers & 1 \\
\hline 21 & Hacker & 2 & 45 & Toz Parçacı̆̆ & 1 \\
\hline 22 & Mikrop & 2 & & & \\
\hline 23 & Dedikodu & 2 & & & \\
\hline 24 & Soğuk Hava & 2 & & & \\
\hline
\end{tabular}

Tablo 2 incelendiğinde, öğrencilerin Covid-19 salgınına ilişkin olarak toplamda 45 farklı metafor üretmiş oldukları görülmektedir. Bu üretilen metaforlardan katılımcıların sıkça kullanmış oldukları metaforlar: "Grip(f:4)", "Bit(f:4)", "Ajan(f:3)", "Deprem (f:3)", "Bakteri(f:3)", 
"Karadelik (f:3)", "Bronşit(f:3)", "Elektrik(f:3)", "Miknatıs(f:3)", "Turist(f:3)”, "Ahtapot(f:3)", "Sigara(f:3)" şeklinde sıralanabilir. Öğrencilerin ürettikleri metaforlar genel olarak incelendiğinde, öğrencilerin tümünün Covid-19 salgınına yönelik olarak olumsuz metaforlar ürettiklerive üretilen metaforların çoğunun salgının hızlı bir şekilde yayılmasıyla ve öldürücülük özelliği ile ilişkilendirildiği görülmektedir.

\section{2. “Covid-19'a Yönelik Üretilen Metaforlar Benzerlik ve Farklılıklarına Göre Hangi Kavramsal Kategoriler Altında Toplanabilir?” Alt Problemine İlişkin Bulgular}

Öğrenciler tarafindan üretilmiş olan 45 farklı metafor değerlendirilmiştir. Değerlendirme sonrasında benzer özellikleri temsil eden metaforlar bir araya getirilmiştir. Benzer özelliklere işaret eden metaforlar tekrardan incelenerek kategorize edilmiştir. Her bir kategori, özelliklerini ifade edecek biçimde isimlendirilmiştir. Bu bağlamda öğrencilerin Covid-19'a yönelik üretmiş oldukları metaforlar sırasıyla "Bulaşıcılık", "Ölümcül”, "Hastalık Yapıcı", "Sosyal Ortamlardan Uzaklaştırıcı", "Geç Fark Edilen" ve "Diğer Hastalıklar ile İlişki” olmak üzere toplam 6 kategori altında gruplandırılarak kategorize edilmiştir. Belirtilen kategoriler altında gruplandırılan öğrenci metaforları sırasıyla açıklanmıştır. Öğrencilerinin Covid-19 salgına yönelik oluşturdukları metaforlara ilişkin kavramsal kategoriler Tablo 2'de sunulmuştur.

Tablo 2: Öğrencilerin Covid-19 Salgına İlişkin Oluşturdukları Metaforlara İlişkin Kavramsal Kategoriler

\begin{tabular}{cc}
\hline Metafor Kategorisi(f:6) & Frekans(N) \\
\hline Bulaşıcılık & 11 \\
Ölümcül & 9 \\
Sosyal Ortamdan Uzaklaştırıcı & 7 \\
Hastalık Yapıcı & 6 \\
Geç Fark Edilen & 6 \\
Diğer Hastalıklar ile İlişkin & 6 \\
Toplam & $\mathbf{4 5}$ \\
\hline
\end{tabular}

Tablo 2 incelendiğinde öğrencilerin Covid-19 salgınına ilişkin 6 farklı kavramsal kategori oluşturduklarıgörülmektedir. Bu bağlamda öğrencilerin Covid-19'a yönelik üretmiş oldukları metaforların sırasıyla "Bulaşıcılık", "Ölümcül”, "Hastalık Yapıcı", "Sosyal Ortamlardan Uzaklaştırıcı","Geç Fark Edilen" ve "Diğer Hastalıklar ile İlişki" kategorileri altında gruplandırılarak kategorize edildiği anlaşılmaktadır. En yüksek frekansta metafor üretilen kategorinin "Bulaşıcılık" kategorisi olduğu anlaşılmaktadır. Öğrencilerin Covid-19 salgınına yönelik oluşturmuş oldukları her bir kavramsal kategoride yer alan metaforlar tablolar halinde sunularak açıklanmıştır. Öğrenciler tarafından üretilmiş olan her bir metafora ilişkin örnek cümlelere de yer verilmiştir.

\section{Bulaşıcllık}

Öğrencilerin oluşturduklanı metaforlardan 11 tanesi, Covid-19 salgınının sahip olduğu kolay yayılma ve bulaşıcı olma nitelikleriyle ilişkilendirilmiştir. $\mathrm{Bu}$ nedenle bu metaforlar bulaşıcılık kategorisi altında toplanmıştır. Bu kategori altında üretilen metaforlar, frekans değerleri göz önüne alınarak Tablo 3 'te sunulmuştur. 
Tablo 3: Bulaşıcılık

\begin{tabular}{cc}
\hline Metafor & Frekans(N) \\
\hline Bit & 4 \\
Elektrik & 3 \\
Miknatıs & 3 \\
Turist & 3 \\
Şımarık Çocuk & 3 \\
Prit & 3 \\
Ahtapot & 3 \\
Yapışkan Top & 2 \\
Radyasyon & 1 \\
Dedikodu & 2 \\
Orümcek Ağ1 & 1 \\
Toplam & $\mathbf{2 8}$ \\
\hline
\end{tabular}

"Bulaşıcılık" kategorisi altında öğrenciler toplam 28 adet metafor üretmişlerdir. $\mathrm{Bu}$ kategori altında en çok tekrarlanan metaforlar: "Bit(f:4)", "Elektrik(f:3)", "Miknatıs(f:3)", "Turist(f:3)", "Şımarık Çocuk(f:3)", "Ahtapot(f:3)" şeklindedir. Öğrencilerin üretmiş oldukları metaforlarda yatan benzetmelerin daha iyi anlaşılabilmesi açısından öğrenci cümlelerine yer verilmiştir. Öğrencilerin bu kategori altında belirtmiş oldukları metaforlara ilişkin doğrudan alıntı örnek cümleleri aşağıdaki gibidir:

"Covid-19 bit gibidir. Çünkü arkadaşımızın saçında olan bit önce yanındaki arkadaşıma sonra da tüm sınıftaki arkadaşlarıma geçer. Böylece hepimizin kafasında bit olur." (Ö29, kız)

"Covid-19 elektrik gibidir. Çünkü yanlışlıkla birimize elektrik çarpsa ona kim dokunursa ona da elektrik çarpar. Koronayı kim kaptıysa onun hastalığı ona dokunan insanlara geçer." (Ö11, erkek)

"Covid-19 mıknatıs gibidir. Çünkü her gördüğü demir parçalarını kendine çeker. Korona da her gördüğ̈̈ insanı hasta olsun diye çeker.”(Ö78, k1z)

"Covid-19 turist gibidir çünkü önce Çin'de çıkmış sonra gezerek tüm dünyaya bulaşarak Türkiye'ye gelmiş.” (Ö81, erkek)

“Covid-19 şımarık çocuk gibidir. Çünkü şımarık çocuklar herkese yapışır ve bırakmaz. Bizi sürekli rahatsız eder.”(Ö68, erkek)

"Covid-19 prit gibidir. Çünkü bir yere sürüldüğ̈̈ zaman her şeyi birbirine yapıştırıyor. Her yer yapıştırıcı oluyor.”(Ö33, kız)

"Covid-19 ahtapot gibidir. Çünkü ahtapotun çok uzun ve sekiz kolu var. Denizin içinde istediği her yere kolunu uzatır.”(Ö49, k1z)

"Covid-19 yapışkan top gibidir. Çünkü yapışkan bir madde nereye atsan oraya yapışabiliyor.”(Ö34, k1z)

"Covid-19 radyasyon gibidir. Çünkü radyasyonun yaydl̆̆g titreşimler her yere gidebilir. Aynı ortamdaki tüm insanlara girerek zarar verir.”(Ö98, kız)

"Covid-19 dedikodu gibidir. Çünkü bir kişi yapsa hemen kalabalıkta her yere ve çabucak yayılır. Korona da öyle. Bir kişi hasta olduğu için hepimiz hasta olduk.”(Ö52, k1z)

"Covid-19 örümcek ăğ gibidir. Çünkü örümcek bir duvara ăg açtı̆̆ında ăg kocaman olur her duvara yayılır.”(Ö22, k1z) 


\section{2. Ölümcül}

Öğrencilerin oluştukları metaforlardan 9 tanesi, Covid-19 salgınının insanları öldürücü niteliğiyle ilişkilendirilmiştir. Bu nedenle bu metaforlar ölümcül kategorisi altında toplanmıştır. Bu kategori altında üretilen metaforlar, frekans değerleri göz önüne alınarak Tablo 4'te sunulmuştur.

Tablo 4: Ölümcül

\begin{tabular}{cc}
\hline Metafor & Frekans(N) \\
\hline Deprem & 3 \\
Karadelik & 3 \\
Yllan Zehri & 3 \\
Kurşun & 3 \\
Silah & 1 \\
Kurt & 1 \\
Kaza & 1 \\
Canavar & 1 \\
Kanser & 1 \\
Toplam & $\mathbf{1 7}$ \\
\hline
\end{tabular}

"Ölümcül" kategorisi altında toplam 17 adetmetafor yer almaktadır. Bu kategori altında en çok tekrarlanan metaforlar "Deprem (f:3)", "Karadelik(f:3)", "Yılan Zehri(f:4)" şeklindedir. Öğrencilerin bu kategori altında belirtmiş oldukları metaforlara ilişkin doğrudan alıntı örnek cümleleri aşağıdaki gibidir:

"Covid-19 deprem gibidir. Çünkü deprem olunca insanlar enkaz altında kalarak nefesleri kesilir ve ölürler. Korondan da çok insanlar ölüyor." (Ö8, erkek)

"Covid-19 karadelik gibidir. Çünkü karadelik yanına yaklaşan herkesi yutar. İnsanları içine çekerek öldürür.”(Ö32, kız)

"Covid-19 yılan zehrii gibidir. Çünkü yılan birini isırırsa yllan zehri onu hemen öldürür.”(Ö63,erkek)

“Covid-19 kurşun gibidir. Çünkü kalbine kurşun atılan biri ölür.”(Ö38, erkek)

“Covid-19 silah gibidir. Çünkü haberde silahla ateş edilenler hep ölüyor.” (Ö41, erkek)

“Covid-19 kurt gibidir. Çünkü kurt kuzuları yiyince kuzular ölüyor.”(Ö6, kız)

"Covid-19 kaza gibidir. Çünkü arabayla yol giderken trafik kazası olur. Kazada arabadakiler yuvarlanarak ölür.”(Ö46, erkek)

“Covid-19 canavar gibidir. Çünkü çizgi filmdeki canavarlar yiyerek yok ederler.”(Ö44,erkek)

"Covid-19 kanser gibidir. Çünkü kanser vücuda girince tüm organlara yayllır ve insan halsizleşir, saçı dökülür. Sonra ölür.”(Ö3, kız)

\section{Hastalık Yapıcı}

Öğrencilerin oluştukları metaforlardan 6 tanesi, Covid-19 salgının insanları hasta edici niteliğiyle ilişkilendirilmiştir. $\mathrm{Bu}$ nedenle bu metaforlar hastalık yapıcı kategorisi altında toplanmıştır. Bu kategori altında üretilen metaforlar frekans değerleri göz önüne alınarak Tablo 5 'te sunulmuştur. 
Tablo 5: Hastalık Yapıcı

\begin{tabular}{cc}
\hline Metafor & Frekans \\
\hline Bakteri & 3 \\
Mikrop & 2 \\
Soğuk Hava & 2 \\
Abur-Cubur & 1 \\
Mantar & 1 \\
Tipeks & 1 \\
Toplam & $\mathbf{1 0}$ \\
\hline
\end{tabular}

"Hastalık Yapıcı" kategori altında toplam 10 adet metafor yer almaktadır. Bu kategori altında en çok tekrarlanan metaforlar: "Bakteri(f:3)", "Mikrop(f:2)", "Soğuk Hava (f:2)"şeklindedir. Öğrencilerin bu kategori altında belirtmiş oldukları metaforlara ilişkin doğrudan alıntı örnek cümleleri aşağıdaki gibidir:

“Covid-19 bakteri gibidir. Çünkü bakteriler bizi halsiz yapar ve sonra hastalanırı..”(Ö35, erkek)

“Covid-19 mikrop gibidir. Çünkü vücudumuza girerek bizi hasta eder.”(Ö18,erkek)

"Covid-19 soğuk hava gibidir. Çünkü hava soğuk olduğunda dikat etmezsek üşütürüz ve ateşimiz çıkar hastalanırız.”(Ö5, kız)

“Covid-19 abur-cubur gibidir. Çünkü kola hamurger yersek midemiz bulanır hasta oluruz.”(Ö21, $\mathrm{k} 1 \mathrm{z})$

"Covid-19 mantar gibidir. Çünkü bazenleri mantar yediğimiz zaman zehirleniriz, çok kötü hasta oluruz.”(Ö57, k1z)

“Covid-19 tipeks gibidir. Çünkü kâğıtta bir yere sürdüğümüz zaman her yer mahvolur.”(Ö37, k1z)

\section{Sosyal Ortamlardan Uzaklaştırıcı}

Öğrencilerin oluştukları metaforlardan 7 tanesi, Covid-19 salgının insanları soyutlayıcı yani izole edici niteliğiyle ilişkilendirilmiştir. $\mathrm{Bu}$ nedenle bu metaforlar sosyal ortamdan uzaklaștırıcı kategorisi altında toplanmıștır. Bu kategori altında üretilen metaforlar frekans değerleri göz önüne alınarak Tablo 6'da sunulmuştur.

Tablo 6: Sosyal Ortamdanlardan Uzaklaştırıcı

\begin{tabular}{cc}
\hline Metafor & Frekans(N) \\
\hline Dikenli Çiçek & 3 \\
Tatil & 3 \\
Kötü İnsan & 2 \\
Kalkan & 1 \\
Kötü Arkadaş & 1 \\
Yalıtım Malzemesi & 1 \\
Demir Parmaklık & 1 \\
Toplam & $\mathbf{1 2}$ \\
\hline
\end{tabular}

"Sosyal Ortamdan Uzaklaştırıcı" kategorisi altında öğrenciler toplam 12 adet metafor üretmişlerdir. Bu kategori altında en çok tekrarlanan metaforlar: "Dikenli Çicek(f:3)", "Tatil(f:3)", "Kötü İnsan(f:2)", "Demir Parmaklık(f:1)", "Yalıtım Malzemesi(f:1)" şeklindedir. Öğrencilerin bu kategori altında belirtmiş oldukları metaforlara ilişkin doğrudan alıntı örnek cümleleri aşağıdaki gibidir: 
"Covid-19 dikenli bir çiçek gibidir. Çünkü okulumuzdan, öğretmenimizden ve arkadaşlarımızdan ayırdı.”(Ö60, erkek)

“Covid-19 tatil gibidir. Çünkü okula gidemiyoruz, hep evde oturuyoruz.”(Ö23, k1z)

“Covid-19 kötü insan gibidir. Çünkü kötü insanlar çok sinsidir insaları birbirinde ayırır.”(Ö39, $\mathrm{k1z)}$

"Covid-19 kalkan gibidir. Çünkü kalkan kullanarak kendimizi diğer insanlardan uzak tutarak engel yaparız."(Ö76, erkek)

"Covid-19 yalıtım malzemesi gibidir. Çünkü binada yalıtım malzemesi kullanarak sesin bize gelmesini önleriz. Koronada misafir gelmesine izin vermiyor.”(Ö87, erkek)

"Covid-19 demir parmaklık gibidir. Çünkü bizim dışarı çıkmamızı engelleyerek eve hapseder.”(Ö9, k1z)

\section{Geç Fark Edilen}

Öğrencilerin oluşturdukları metaforlardan 6 tanesi, Covid-19 salgınının vücuda yerleştiği zaman kulukça süresi dolmadan farkına varılamayan niteliğiyle ilişkilendirilmiştir. Bu nedenle bu metaforlar geç fark edilen kategorisi altında toplanmıştır. Bu kategori altında üretilen metaforlar, frekans değerleri göz önüne alınarak Tablo 7'de sunulmuştur.

Tablo 7: Geç Fark Edilen

\begin{tabular}{cc}
\hline Metafor & Frekans(N) \\
\hline Ajan & 3 \\
Hacker & 2 \\
Hile & 1 \\
Yalan & 1 \\
Küçük Tanecik & 1 \\
Toz Parçacığı & 1 \\
Toplam & $\mathbf{9}$ \\
\hline
\end{tabular}

"Geç Fark Edilen" kategorisi altında öğrenciler toplam 9 adet metafor üretmişlerdir. $\mathrm{Bu}$ kategori altında en çok tekrarlanan metaforlar: "Ajanda(f:3)", "Hacker(f:2)", "Yalan(f:1)" şeklindedir. Öğrencilerin bu kategori altında belirtmiş oldukları metaforlara ilişkin doğrudan alıntı örnek cümleleri aşağıdaki gibidir:

“Covid-19 ajan gibidir. Çünkü insanların vücuduna sinsice girer. Hasta ettikten sonra fark edilir. "(Ö42, erkek)

"Covid-19 hackergibidir. Çünkü vücudumuzun koruma sistemini çökerttikten sonra vücuda girdiğini anlarız.”(Ö72, kız)

“Covid-19 hile gibidir. Çünkü gizlice arkamızdan iş çevirdiğini sonra görürüz.”(Ö43, kız)

"Covid-19 yalan gibidir. Çünkü birine yalan söyleyince onu kandırırız. O sonradan yalan söylediğimizi anlar.”(Ö97, erkek)

“Covid-19 küçük tanecik gibidir. Çünkü gözümüzle göremediğimiz parça olarak vüdümuza girer.”(Ö48, erkek)

“Covid-19 toz parçacı̆̆ı gibidir. Ağzımıza girerken fark etmeyiz. Boğazımıza yapışıp bizi öksörtür ve boğazımızı yakar.”(Ö17, erkek) 


\section{Diğer Hastalıklar İle İlişki}

Öğrencilerin oluşturdukları metaforlardan 6 tanesi, Covid-19 salgınının diğer rahatsızlıklarla benzer etkiler göstermesi nitelikleğiyle ilişkilendirilmiştir. Bu nedenle bu metaforlar diğer hastalıklar ile ilişki Covid-19 kategorisi altında toplanmıştır. Bu kategori altında üretilen metaforlar, frekans değerleri göz önüne alınarak Tablo 8'de sunulmuştur.

Tablo 8: Diğer Hastalıklar İle İlişki

\begin{tabular}{cc}
\hline METAFOR & FREKANS \\
\hline Grip & 4 \\
Bronşit & 3 \\
Sigara & 3 \\
Sars & 2 \\
Mers & 1 \\
Gıcık & 1 \\
Toplam & $\mathbf{1 4}$ \\
\hline
\end{tabular}

"Diğer Hastalıklar İle İlişki" kategorisi altında öğrenciler toplam 14 adet metafor üretmişlerdir. Bu kategori altında en çok tekrarlanan metaforlar: "Grip(f:4)", "Bronşit(f:3)", "Sigara(f:3)", "Sars(f:2)" şeklindedir. Öğrencilerin bu kategori altında belirtmiş oldukları metaforlara ilişkin doğrudan alıntı örnek cümleleri aşağıdaki gibidir:

"Covid-19 grip gibidir. Çünkü grip olduğumuz korona gibi ateşimiz çıkar, halsiz oluruz ve öksürürüz." (Ö4, k1z)

"Covid-19 bronşit gibidir. Çünkü bir kere bronşit olduğumda nefe almakta zorlanmıştım." (Ö13, erkek)

"Covid-19 sigara gibidir. Çünkü sigara içen insanların akciğerleri çok zarar görür. Korona da ciğerlere yayılıp çok kötü yapar.” (Ö92, erkek)

"Covid-19 sars gibidir. Çünkü haberlerdeki doktorlar önceden olan bu virüse çok benziyor dediler." (Ö47,erkek)

"Covid-19 mers gibidir. Çünkü ikisi de zarar veren virüs." (Ö82, erkek)

“Covid-19 gıcıkgibidir. Çünkü bizi gıcık tuttu mu rahatlayana kadar çok öksürürüz.” (Ö12, erkek)

\section{Tartışma ve Sonuç}

Metaforlar bireylerin hayatı, çevreleri, olayları ve nesneleri ne şekilde gördüklerine yönelik farklı benzetmeler yaparak açıklamalarına imkân tanımaktadırlar (Cerit, 2008:694). Bununla beraber metafor analizlerinin zihinsel imgeleri açığa çıkarmak amacıyla araştırmacılar tarafından sıklıkla kullanılmakta olduğu görülmektedir (Polat, Apak ve Akdağ, 2013:62). Mart ayı içerisinde ülkemizde ortaya çıkan Covid-19 salgını, gündelik yaşam akışını durdurmuş ve toplumu tamamen etkisi altına almıştır. Bu etki ister istemez eğitim alanına da yansıyarak kendini göstermiştir. Birdenbire ortaya çıkan ve hızla yayılım gösteren bu salgın sebebiyle, uzak eğitime geçilmesinin eğitim yaşamını etkilemiş olduğu söylenebilir. Eğitimin esas öznesi olduğu düşünülen öğrencilerin ise bu durumdan etkilenmemesi kaçınılmaz olacaktır. Dolayısıyla bu salgının, her bir öğrenci zihninde farklı olarak algılanmış olabileceği beklenmektedir. Araştırma doğrultusunda çalışmaya katılım gösteren öğrencilerden toplamda 45 adet geçerli metafor elde edilmiştir. Öğrenciler tarafından Covid-19'a yönelik üretilen metaforlar sırasıyla "Bulaşıcılık", "Ölümcül", "Hastalık Yapıcı", "Sosyal Ortamlardan Uzaklaştırıcı", "Geç Fark Edilen” ve "Diğer Hastalıklar ile İlişki" üzere toplam 6 tema altında gruplandırılarak kategorize edilmiştir. Öğrencilerin üretmiş oldukları metaforlar incelenirken metafor özelliği göstermeyen 10 adet veri çalışma dışında tutulmuştur. 
Dolayısıyla da çalışmaya katılım gösteren öğrencilerin \%90’ının Covid-19 salgınına ilişkin algılarını metafor yoluyla açıklayabildikleri; \%10'unun ise metafor yoluyla açıklayamadığ1 söylenebilir. Öğrenciler tarafından üretilen Covid-19 metaforlarının tümünün gerekçeleri incelendiğinde, üretilen metaforların olumsuz nitelikte olduğu görülmüştür. Nitekim ortaya çıkan bu salgının öğrenciler üzerinde olumsuz anlamda etki oluşturduğunun söylenmesi doğru olacaktır. $\mathrm{Bu}$ durum, sürekli olarak medya gündeminde Covid-19 hastalığı nedeniyle yaşanan ölümleri ve artan pozitif vaka sayılarını duyan öğrencilerin, bu salgını zihinlerinde olumsuz düşünceler ile özdeşleştirmiş oldukları gerekçesiyle açıklanabilmektedir.

Öğrenciler Covid-19 algılarını en çok grip, bit, ajan, deprem, karadelik, bakteri metaforlarına; en az yalan, radyasyon, gıcık, kanser, toz parçacığı, hilemetaforlarına benzetmişlerdir. Frekans sıklıkları incelendiğinde, üretilen metaforların en fazla bulaşıcılık ve öldürücülük kategorileri altında yer aldığı anlaşılmaktadır. Öğrenciler bu virüsün hızlı bir şekilde yayıldığını ve birçok insanın ölümüne sebep olduğunu belirtmişlerdir. Sağlık örgütünün verileri açıklanan verilerince her geçen gün dünya üzerinde binlerce insanın yaşamını kaybetmesi, Covid19'un tüm dünyayı etkisi altında alan ve gittikçe artış gösteren ölümlere neden olan bir pandemi olduğunun göstergesidir. Öte yandan bu virüsü taşıyan bireylerin yüksek potansiyelde bulaştırıcı etkiye sahip olmaları, bu süreçtekritik yol oynamaktadır (Jin ve ark. 2020; Shen ve ark. 2020). Dolayısıyla da öğrencilerin salgına yönelik üretmiş oldukları hızlı yayılma ve öldürücü olma metaforlarının desteklenmekte olduğu söylenebilir.

Araştırmada "Bulaşıcılık" kategorisinde; bit, ahtapot, elektrik, dedikodu, turist, radyasyon, şımarık çocuk metaforları üretilmiştir. Bu metaforlar ile covid-19 hastalığının hızlı yayılım göstererek bulaştığ belirtilmiştir. Covid-19 salgının dur durak bilmeden çok hızlıca ve her noktaya yayılabileceği olgusuna öğrenci metaforlarından kolayca ulaşılabilir. Covid-19 hastalığının araştırılması sonucu; insandan insana geçiş ile yayılması Covid-19'un en önemli özelliği olup, hastanın hasta olduğu süreçte hastalığı çevreye yaydığı tespit edilmiştir (Karcıoğlu, 2020:64). Öğrenciler tarafından üretilen en yüksek metafor frekansına sahip Covid-19 hastalığının bulaşıc1 kategorisi burada öne çıkmaktadır.

Araştırmada "Ölümcül” kategorisinde; deprem, yılan zehri, karadelik, silah, kurşun, kaza metaforları öğrenciler tarafindan üretilmiştir. Bu metaforlar ile öğrenciler virüsü, yarattı̆̆ 1 ağır etkiler ile insanların hastalığa yenik düşmelerine sebep olarak can kayıplarına yol açtığını belirtmek istemişlerdir. Covid-19 salgınına yönelik yapılan çalışmalar Covid-19'un, Sars ve Mers hastalıklarının toplamından daha fazla zarara ve ölüme yol açmış olduğunu göstermektedir (Karcıoğlu,2020:56). Çalışmamıza katılım sağlayan öğrencilerin ise virüsün insanlar üzerinde yarattığı öldürücüyü etkiye dönük birçok metafor oluşturmuş oldukları tespit edilmiştir. Öğrencilerin Covid-19 salgınına ilişkin ölümcül kategorisinde üretilen metaforların, virüsün öldürücü özelliğinden yola çıkarak oluşturulması bu yönüyle desteklenmiş olduğu görülmektedir.

Araştırmada "Diğer Hastalıklar ile İlişki" kategorisinde; grip, sars, bronşit, sigara, mers, gıcık metaforları öğrenciler tarafından üretilmiştir. Bu metaforlar ile insanlarda ateş, öksürük, halsizlik vb. semptomlar gösteren covid-19 hastalığının bazı diğer rahatsılıklar ile benzer özellikte olduğunu belirtmişlerdir. Öğrenciler, bu virüsün Mers veya Sars kaynaklı olabileceğine ve bu iki virüs gibi etkileri olduğuna dair metafor üretmişlerdir. 2002 sonu ve 2003 başında Uzakdoğu'da milyonlarca kişiyi etkileyen ve ölümlere yol açan, yabani kedilerden geçen Sars da bu virüs ailesinin üyesi olarak açıklanmıştır. Diğer yandan sağlık kaynakları incelendiğinde, Covid-19'un Sars ve Mers virüslerine benzer olduğunun belirtildiği göze çarpmaktadır (Chowel ve Abdirizak, 2015; Leung ve Hedley, 2003; Aktaran: Ovalı, 2020: 24). Dolayısıyla da öğrencilerin, Covid-19 hastalığına neden olan virüsü Mers ve Sars virüsleriyle özdeştirilmesine yönelik olan metaforlarının doğruluk payının olduğu söylenebilir. Öğrencilerin, onlar için uzak geçmiş sayılabilecek zamanda görülen Mers ve Sars virüslerini bilmiş olmaları ve bundan ziyade Covid-19 salgınıyla benzerlik kurabilmiş olmaları dikkat çekmektedir. Bu durum üzerine düşünülecek olursa, 
medyada çıkan haberler, sürekli görüş bildiren uzmanlar ve hatta aile üyelerinin aralarında yapmış oldukları konuşmaların öğrenci zihni üzerinde böyle bir algının oluşturulduğuna kaynaklık ettiği öne sürülebilir. Diğer yandan diğer hastalıklar ile ilişki altında öğrencilerin grip metaforunu üretmiş olduğu görülmektedir. Öğrenciler Covid-19 hastalığının gripte olduğu gibi öksürük, ateş gibi benzer semptomlar içermesi sebebiyle bu iki virüsü birbirine benzeterek metafor oluşturmuş oldukları anlaşılmaktadır. Covid-19'un yaygın semptomları ateş, yorgunluk ve kuru öksürük olarak tanımlamıştır. Bunun yanında nefes darlığı, boğaz ağrısı ve çok az kişide ishal rapor edilmiştir.(WHO, 2020). -Öte yandan Guan ve arkadaşları (2020:64), bu salgının en sik görülen olgu bildirimlerinde ateş, kuru öksürük, bulantı-kusma, halsizlik gibi yakınma ve bulgular ağırlıklı olduğunu belirtmiştir. Bu bilgiler, öğrenci metaforlarıyla Covid-19 hastalığının diğer günlük yaşamda karşı karşıya kaldığımız rahatsızlıklara ilişkin yapılan benzetmelere dayanak sağlamıştır denebilir. Bu kategoride yer alan diğer metafor algısı ise sigaradır. Öğrencilerin hem Covid-19 hem de sigaranın akciğerde ve bronşlarda bıraktıkları yaygın hasardan dolayı bu metaforu oluşturdukları görülmektedir. Bu hasar benzerliğinin, farkına nasıl varmış oldukları üzerine düşünülmüştür. Kamu spotlarında görüntülenen sigara tüketen bireyin akciğer modeliyle, haberlerde yer verilen virüslü akciğer görüntüsünü özdeşleştirmiş olabilecekleri akıllara getirmiştir.

Araştırmada "Sosyal Ortamlardan Uzaklaştırıcı" kategorisinde; tatil, yalıtım malzemesi, dikenli çiçek metaforları öğrenciler tarafından üretilmiştir. Bu metaforlar ile öğrenciler, virüsün ortaya çıkmasıyla okula gidemediklerini, öğretmenlerinden ve arkadaşlarından uzak kaldıklarını belirtmişlerdir. Covid-19 salgınının yayılmasını önlemek amaçlı sağlık bakanlığı tarafından mecbur kalmadıkça evden çıkılmaması uyarıları ısrarla yapılmaktaydı. Buna ek olarak sonraki süreçte çıkan kararla 20 yaş altı ve özellikle çocukların dışarı çıkmamasına yönelik yasak getirilmişti. Bu nedenle çocukların bu salgın nedeniyle artık evden çıkmaması, okula gidememesi ve arkadaşlarıyla vakit geçirmemesi onları etkilemiştir. Dolayısıyla da öğrencilerin soyutlayıcı metaforları kullanarak yaptıkları benzetmeler ile bu durumu ifade ettiklerini söyleyebiliriz. Pandemi süreci boyunca çocukların açık havada ve dışarıda oynan oyunlarının \%91 oranında düşüşe geçtiği ve arkadaşlarıyla oynama oranının $\% 80.5$ oranında azaldığ gösterilebilmektedir (Mart ve Kesicioğlu, 2020:956).

Araştırmada "Geç Fark Edilen" kategorisinde; ajan, hacker, hile, yalan, toz parçacığ 1 metaforları öğrenciler tarafından üretilmiştir. Bu metaforlar ile vücuda giren virüsün girdiği andan itibaren etkisini göstermediği, belirli bir kuluçka süresini tamamladıktan kendini bazı semptomlarla gösterdiği belirtilmeye çalışılmıştır. Covid-19 hastalığına yönelik gerçekleştirilen araştırmalar incelendiğinde kuluçka süresi 1-14 gün arasında değişmekle beraber ortalama 5,2 gündür ve semptomatik hastaların \%97'sinde semptomların 10,5 gün içinde çıkmakta olduğu bilgisine ulaş1lır (Lauer ve Grantz, 2020). Bu doğrultuda öğrencilerin virüsün etkilerinin geç fark edildiğine ilişkin üretmiş oldukları metaforların doğrulandığı söylenebilir.

Alan yazında gerçekleştirmiş olduğumuz çalışmaya benzer sonuçları mukayese edebileceğimiz, Covid-19 salgınına ilişkin olarak yapılan bir metaforik araştırmaya rastlanmamıştır. Ancak öğrencilerin Covid-19 salgınına ilişkin ürettikleri metaforlar diğer metafor çalışmalarda üretilen bazı metaforlar ile örtüşmektedir. Yılmaz, Özer ve Fettahoğlu (2020:121), sağlık alanına yönelik bir metafor çalışmasında üretilen "Ahtapot" metaforu "Çok Yönlü Olması" kategorisi altında yer almaktadır. Çalı̧̧mamızda üretilen "Ahtapot" metaforu ise "Etkin Bir Bulaşıcı Olarak Covid-19" kategorisi altında yer verilmiştir. Her iki çalışmada da üretilen ahtapot metafor, iki çalışmada da çok farklı anlamlandırılmış görünse de aslında birbirine yakındır. Çünkü araştırmamızdaki ahtapot metaforu Covid-19 salgının, tıpk1 ahtapot kolları gibi her yere uzanıp yayılabildiği anlamı belirtirken; diğer araştırmada sağlık yöneticisinin de her dala uzanıp ulaşabildiği anlamını belirtir. Bu da aslında birbirine uzak gibi görülen kategorilerde yer alan iki metaforun, her iki çalışmada da yakın ilişki içerisinde olduğu söylenebilir. Yine aynı çalışmada üretilen diğer bir metafor ise "Karadelik" metaforudur. Araştırmamızda üretilen karadelik metaforunda, Covid-19 salgının insanları bir karadelik gibi içine çekerek, salgına yakalanan 
bireyleri öldürmeyinceye kadar bırakmamasına benzetilmiştir. Diğer çalışmada ise sağlık çalışanlarının, çalışma alanının çok geniş olması ve sahip olduğu sorumlulukları çok fazla olmasıyla ilişkilendirildiği görülür (Yılmaz, Özer ve Fettahoğlu, 2020: 121,122). Karadelik metaforu açısından her iki çalışmada yüklenilen anlamlar çok benzer olmasa dakaradeliğin geniş olması ve içine çekme anlamıyla nitelendirilmesi benzerdir diyebiliriz.

Beyoğlu ve Ergin (2019:290), öğretmen adaylarına yönelik gerçekleştirdikleri bir çalışmada, öğretmenlerin şiddet kavramına yönelik metaforlarını ortaya çıkarmaya çalışmışlardır. Bu çalışmada üretilen deprem metaforu "Fiziksel Olarak Şiddet" kategorisi altında yer almıştır. Çalışmamızda üretilen "Deprem" metaforuna ise "Öldürücü Bir Etki Olarak Covid-19" kategorisi altında yer verilmiştir. Her iki çalışmada da üretilen deprem metaforu iki çalışmada da çok farklı anlamlandırılmış görünse de aslında birbirine yakındır. Araştırmamızda üretilen deprem metaforu Covid-19 salgının, deprem gibi insanlarda çok yıkıcı bir etki yarattığı ve hatta ölümlere sebep olduğu özelliği özdeşleştirmiştir. Diğer araştırmada ise deprem metaforu şiddetin insanlar üzerinde bıraktığ1 etkiler ve zararlar ile ilişkilendirilmiştir. Bu doğrultuda her iki araştırmada da depremin kişiler üzerinde bıraktığı olumsuz etkiler ön plana çıkarılmıştır.

\section{Öneriler}

Araştırma sonucu gösteriyor ki Covid-19 hastalığı öğrenciler üzerinde olumsuz algılar oluşturmuştur. Öğrencilerin tümü Covid-19'u öldürücü, hasta edici, bulaşıcı ve sosyal hayatı olumsuz anlamda etkileyen bir virüs olarak algılamışlardır. Bu bağlamda öncelikle yapılması gereken, öğrenciler üzerinde oluşan bu olumsuz etkinin ortadan kaldırmasıdır. $\mathrm{Bu}$ süreçte öğretmenler, bu sürecin geçici olduğunu, gerekli önlemler alındığında bu salgından zarar görülmeden kurtulabilineceğini öğrencilere kavratabilmelidirler.

Öğrencilerin Covid-19 salgınını bulaşıcılık ve öldürücülük özellikleriyle ilişkilendirmişlerdir. Öğrencilerin bu zihin algılarının giderilmesi amacıyla, öğrencilere alınacak basit önlemler ve izole etme işlemleriyle bu virüse karşı konulabileceği açıklanmalıdır. Sosyal faaliyetlere ara verilerek, kalabalık ortamlardan uzak durularak, gereken hijyen tedbirleri uygulanarak salgının bulaşma riskinin azaltılabileceği anlatılmalıdır.

Diğer yandan öğrenciler Covid-19 salgınını sosyal ortamlardan uzaklaştıran bir etki olarak nitelendirmişlerdir. Öğrencilere ev ortamlarında aileleriyle vakit geçirebileceği eğitsel oyunlar oynatılabilir. Ayrıca bu eğitsel oyunların, ders anlatımlarının gerçekleştirildiği platformlarda arkadaşları ve öğretmenleriyle birlikte oynabilme olanağı oluşturulabilir. Virüs salgının toplumsal olarak uygulanan tedbirler ile bir gün sona ereceği, okulların yüz yüze eğitime dönüş yapacağı ve sosyal yaşamın tekrardan aktif hale geleceği ifade edilmelidir.

Gerek duyulması halinde öğrencilerin rehberlik hizmetlerinden faydalanmaları sağlanarak olumsuz algıları yok edilmelidir. Özellikle bu süreçte öğretmenlerimiz öğrencileri ile işbirliği içerisinde olarak, eğitsel anlamda yaşanılacak kayıpları en aza indirme görevini üstlenecektir (Külekçi Akyavuz ve Çakın, 2020:734). Covid-19'un sadece öğrenciler üzerinde değil, öğretmenler, veliler ve yöneticiler üzerinde de oldukça önemli etkileri olduğundan, öğrencilerin yanı sıra farklı örneklem gruplarının dâhil edildiği yeni çalışmaların yapılmasının da alana katkı sağlayabileceği düşünülmektedir.

\section{Kaynakça}

Abay, Ş. E. (2017). Hekim Adaylarının Hekim Kimliğine İlişkin Algıları: Hacettepe Üniversitesi Tıp Fakültesi Metafor Analizi Örneği. STED/Sürekli Tıp Eğitimi Dergisi, 26(1), 1-8. 
Akın, M.A. ve Minaz, M.B. (2018). Metaphoric Perceptions Of Secondary School Students Related To Central Examination. International Journal of Progressive Education (IJPE), 14(6), 152-167.

Akyavuz, E. K. ve Çakın, M. (2020). Covid-19 Salgınının Eğitime EtkisiKonusunda Okul Yöneticilerinin Görüşleri. Electronic Turkish Studies, 15(4),723-737.

Arslan, M. M. ve Bayrakçı, M. (2006). Metaforik Düşünme ve Öğrenme Yaklaşımının Eğitim Öğretim Açısından İncelenmesi. Milli Ĕgitim Dergisi. 35(171), 100-108.

Arslan, A. ve Zengin, R. (2016). Fen Bilgisi Öğretmen Adaylarının Küresel Isınma Kavramına İlişkin Algılarının Metafor Analizi Yoluya İncelenmesi. The Journal of Academic Social Science Studies, 3(44), 453-466.

Aydeş, S. S. ve Uğur, A. (2016). Okul Yöneticilerinin Öğretmenlere Yönelik Metaforik Algıları. Sakarya University Journal Of Education, 20-39.

Beyoğlu, A. ve Ergin, D. (2019). Öğretmen Adaylarının Şiddet Kavramına İlişkin Algılarının Metafor Analizi Yoluyla İncelenmesi. Trakya Üniversitesi Sosyal Bilimler Dergisi, 21 (1), 283-294.

Botha, E. (2009). Why Metaphor Matters in Education. South African Journal of Education, 29(4), 431-444.

Bülbül, T. ve Toker Gökçe, A. (2015). Meslek Lisesi Öğrencilerinin Metaforik Algıları: İşlevselci Bir Yaklaşım. Ahi Evren Üniversitesi Kırşehir Eğitim FakültesiDergisi(KEFAD), 16(2), 273-291.

CDC, (2013). (Centers for Disease Control and Prevention, \& Centers for Disease Control and Prevention.). Winnable Battles Final Report. Erişim Tarihi: 24.03.2020, https://www.cdc.gov/winnablebattles/report/docs/winnable-battles-final-report.pdf.

Cerit, Y. (2008). Öğretmen Kavramı ile İlgili Metaforlara İlişkin Öğrenci, Öğretmen ve Yöneticilerin Görüşleri. Türk Eğitim Bilimleri Dergisi. 6 (4), 693-712.

Chowell, G., Abdirizak, F., Lee, S., Lee, J., Jung, E., Nishiura, H. ve Viboud, C. (2015). Transmission Characteristics of MERS and SARS in The Healthcare Setting: a Comparative Study. BMC Medicine, 13(1), 210.

Creswell, J. W. (2015). Araştırma Deseni (Çev Edt Demir, S. B.). Ankara: Eğiten Kitap.

Ekici, G. (2016). Öğretmen Adaylarının 'Bilgisayar' Kavramına İlişkin Metaforik Algıları. University of Gaziantep Journal of Social Sciences, 15(3), 755-781.

Erişti, S. D. (2014). Uluslararası Erasmus Programı Çerçevesinde Türkiye'ye Gelen Sanat ve Tasarım Öğrencilerinin Türk Kültürü Algıları. Anadolu Journal of Eductional Sciences International, 4(2), 82-107.

Er-Türküresin, H., Başer, E. H., ve Yapıcı, H. (2018). Ortaokul Öğrencilerinin Dayanışma Kavramına İlişkin Algılarının Metaforlar Yoluyla İncelenmesi. Kuramsal Eğitimbilim Dergisi (UBEK), 61-80.

Eskici, G. (2020). Covid-19 Pandemisi: Karantina İçin Beslenme Önerileri. Anatolian Clinic The Journal Of Medical Sciences, 25 (Supplement 1), 124-12.

Geçit, Y. ve Gençler, G. (2011). Sınıf Öğretmenliği 1. Sınıf Öğrencilerinin Coğrafya Algılarının Metafor Yoluyla Belirlenmesi (Rize Üniversitesi Örneği), Marmara Coğrafya Dergisi, 23(0), 1-19. 
Gökçay, G. ve Keskindemirci, G. (2020). Anne Sütü ve Covıd-19. Journal of Istanbul Faculty of Medicine, 50-55.

Guan WJ, Ni ZY, Hu Y, et al. Clinical Characteristics of Coronavirus Disease 2019 in China. N Engl J Med. 2020 Feb 28. [Epub ahead of print]

Gümüsgül, O. ve Aydoğan, R. (2020). Yeni Tip Koronavirüs-Covid 19 Kaynaklı Evde Geçirilen Boş Zamanların Ev İçi Rekreatif Oyunlar ile Değerlendirilmesi. Spor Eğitim Dergisi, 4 (1), 107-114.

Güneş, A. ve Fırat, M. (2016). Açık ve Uzaktan Öğrenmede Metafor Analizi Araştırmaları. Açıöğretim Uygulamaları ve Araştırmaları Dergisi, 2(3),115-129.

İnce, D. İ., Yağli, N. V., Sağlam, M. ve Kütükcü, E. Ç. (2020). Covıd-19 Enfeksiyonunda Akut ve Post-Akut Fizyoterapi ve Rehabilitasyon. Türk Fizyoterapi ve Rehabilitasyon Dergisi, 31(1), 81-93.

Jin, YH., Cai, L., Cheng, ZS., Cheng, H., Deng, T., Fan, YP., et al. (2020). A rapid advice guideline for the diagnosis and treatment of 2019 novel coronavirus (2019-nCoV) infected pneumonia (standard version). Military Medical Research, 7(4),

Kalayc1, S. ve Yoğun, C. (2018). Ortaokul Öğrencilerinin “Alyuvar”,“Akyuvar” ve "Kan Pulcukları" Kavramları Hakkındaki Algılarının Metafor Yoluyla İncelenmesi. OPUS Uluslararası Toplum Araştırmaları Dergisi, 8(14), 188-216.

Karcioğlu, Ö. (2020) What Is Coronaviruses, and How Can We Protect Ourselves? Anka Tip Dergisi, 2(1), 66-71.

Karcıoğlu, Ö. (2020). Epidemiyolojik Bilgilerimiz ve Hastalığın Dünyadaki Gidişi. Journal of ADEM, 1(1), 55-71.

Kılcan, B. (2017), Metafor ve Eğitimde Metaforik Çalışmalar İçin Bir Uygulama Rehberi, Ankara: Pegem Akademi.

Kurt, H. S. ve Sarı, M. (2018). Fizik Öğretmeni Adaylarının Elektrik Konusunda Bazı Kavramlara Ait Metaforik Alg1lar1. Erciyes Journal of Education, 2(1), 64-90.

Lauer, S. A., Grantz, K. H., Bi, Q., Jones, F. K., Zheng, Q., Meredith, H. ve Lessler, J. (2020).The Incubation Period of 2019-Ncov From Publicly Reported Confirmed Cases: Estimation and Application. Medrxiv.

Leung, G. M., Hedley, A. J., Ho, L. M., Chau, P., Wong, I. O., Thach, T. Q., ... ve Ferguson, N. M. (2004). The Epidemiology of Severe Acute Respiratory Syndrome In The 2003 Hong Kong Epidemic: An Analysis Of All 1755 Patients. Annals Of Internal Medicine, 141(9), 662673.

Mayring, P.(2011).Nitel Sosyal Araştırmaya Giriş(1.Baskı)(Çev. A. Gümüşs ve M. S. Durgun). Ankara: BilgeSu Yayınları.

Mart, M. ve Kesicioğlu, O. S. (2020). COVID-19 Pandemi Sürecinde Ailelerin Evde Oyun Oynamaya İlişkin Görüşleri. Electronic Turkish Studies, 15(4), 945-958.

MEB(2020). Milli Eğitim Bakanlığı Raporu, Mart 2020.

Merriam,S.B.(2013). Nitel Araştırma: Desen ve Uygulama İçin Bir Rehber. Ankara: Nobel Yayınları.

Miles, M. B. ve Huberman, A. M. (2016). Nitel Veri Analizi (Çev. Ed. Akbaba Altun, S. veErsoy, A.). Ankara: Pegem Akademi. 
Ovalı, F. (2020). Yenidoğanlarda Covid-19 Enfeksiyonları. Anatolian Clinic The Journal of Medical Sciences, 25 (Supplement 1), 23-35.

Öksüz, Y. ve Çevik Kansu, C. (2014). Sınıf Öğretmeni Adaylarının Okuldışı Etkinlik Kavramına Yükledikleri Metaforlar1. The Journal of Academic Social Science Studies, 8(29), 53-65.

Patton, Q. M. (2014). Nitel Araştırma ve Değerlendirme Yöntemleri (Çev. Bütün, M.ve Demir, S.B) Ankara: Pegem Akademi.

Polat, S., Apak, Ö. ve Akdağ, M. (2013). Sınıf Öğretmeni Adaylarının Akademisyen Kavramına İlişkin Algılarının Metafor Analizi Yoluyla İncelenmesi. İnönü Üniversitesi Eğitim Fakültesi Dergisi, 14(2), 57-78

Saban, A. (2008). Okula İlişkin Metaforlar. Kuram ve Uygulamada Eğitim Yönetimi, 55(55), 459496.

Saban, A. (2009).Öğretmen Adaylarının Öğrenci Kavramına İlişkin Sahip Oldukları Zihinsel İmgeler. Türk Eğitim Bilimleri Dergisi, 7 (2), 281-326.

Sarı, T. ve Nayır, F. (2020). Pandemi Dönemi Eğitim: Sorunlar ve Fırsatlar. Electronic Turkish Studies, 15(4), 959-975.

Shaw, D. M.ve Mahlios, M. (2011). Literacy metaphors of pre-service teachers: do they change after instruction? Which metaphors are stable? How do they connect to theories?. Journal of Education for Teaching, 37(1), 77-92.

Shen, K., Yang, Y., Wang, T., Zhao, D., Jiang, Y., Jin R., et al. (2020). Diagnosis, treatment, and prevention of 2019 novel coronavirus infection in children: experts' consensus statement. World Journal of Pediatrics, 16, 223-231.

Taş, H (2019). İlkokul Öğrencilerinin Din Kültürü ve Ahlak Bilgisi Dersi ile Din Kültürü ve Ahlak Bilgisi Öğretmenine İlişkin Metaforları. Cumhuriyet İlahiyat Dergisi, 23(1), 29-51.

T.C. İçişleri Bakanlığı, 81 Il Valiliğine Coronavirüs Tedbirleri Konulu, 16.03.2020.

T.C. Sağlık Bakanlığı, Covid-19 Rehberi, Mart 2020.

Telli, S. G. ve Altun, D. Coronavirüs ve Çevrimiçi (Online) Eğitimin Önlenemeyen Yükselişi. Üniversite Araştırmaları Dergisi, 3(1), 25-34.

THSK, (2014). (Sağlık Bakanlığı Türkiye Halk Sağlığı Kurumu, 2014). Çocuk ve Ergenlerde Fiziksel Aktivite. Türkiye Fiziksel Aktivite Rehberi. Ankara: Kuban Matbaac1lık.

Tırmıkçıŏlu, Z. (2020). Covıd-19 Enfeksiyonu Olan Gebelerde İlaç Kullanımı. Anatolian Clinic The Journal Of Medical Sciences, 25 (Supplement 1) , 51-58.

Türkiye Çocuk ve Genç Psikiyatrisi Derneği Covıd-19 (Korona) Virüs Salgını Sırasında Aile, Çocuk ve Ergenlere Yönelik Psikososyal ve Ruhsal Destek Rehberi, Mart, 2020.

Uğurlu, Z. (2018). Öğretmen Adaylarının Üniversite Kavramına İlişkin Algılarının Metafor Analizi. Çă̆daş Yönetim Bilimleri Dergisi, 5 (1) , 82-97.

WHO (2020) Health Topics. Coronavirus. https://www.who.int/health-topics/coronavirus\#tab=tab_3 Erişim Tarihi 01.04.2020.

Yıldırım, A. ve Şimşek, H. (2018). Sosyal Bilimlerde Nitel Araştırma Yöntemleri. Ankara: Seçkin Yayınc1lı.

Yıldırım, K. (2010), Nitel Araştırmalarda Niteliği Artırma. İlköğretim Online, 9(1), 79-92. 
Y1lmaz, N., Özer, E. ve Fettahoğlu, R. (2020). Sağl1k Yöneticisi Kavramına İlişkin Bir Metafor Analizi. Anemon Muş Alparslan Üniversitesi Sosyal Bilimler Dergisi, 8(1), 115-124.

Zhong, R. (2020). The Coronavirus Exposes Education's Digital Divide. nytimes.com: Erişim tarihi: $\quad 18.03 .2020 \quad$ https://www.nytimes.com/2020/03/17/technology/china-schools coronavirus.html adresinden alınd. 